\title{
The Mythopoetics of Chinua Achebe's Anthills of the Savannah
}

\author{
John Aning, Confidence Gbolo Sanka*, Francis Elsbend Kofigah \\ Department of English, Kwame Nkrumah University of Science and Technology (KNUST), Kumasi, Ghana.
}

Corresponding Author: Confidence Gbolo Sanka* E-mail: Cgsanka.cass@knust.edu.gh

\section{ARTICLE INFO}

Article history

Received: December 04, 2017

Accepted: January 15, 2018

Published: January 31,2018

Volume: 6 Issue: 1

Conflicts of interest: None

Funding: None

\section{Key words:}

Bible, corruption,

Deconstruction,

Metaphor,

Myth making,

Nigeria,

Political leadership,

tradition

\begin{abstract}
The objective of this paper is to investigate how Chinua Achebe uses myth making as an attempt to address the leadership problem of his country, Nigeria. Many writers have identified leadership as the greatest problem of many countries in Africa. Consequently, Achebe uses symbolism and a language replete of violence to portray the levels of corruption and abuse of power in the novel. In this paper, we present a myth criticism of Achebe's Anthills of the Savannah by looking at how the novelist deconstructs Biblical and traditional stories to show that women should be given a greater political role alongside men to chart a new course of development. Achebe's novel is dominated by the myth of the Pillar of Fire which he takes from the Bible and the Idemili myth which he takes from the traditions of his people. At the end of the deconstruction of these two myths, the only viable alternative left is the all-inclusive group led by the priestess of Idemili and hope is finally enshrined in the baby girl Amaechina.
\end{abstract}

\section{INTRODUCTION}

Myth making is the exploitation of the symbolic, metaphoric and the allegorical resources of a Biblical, classical or a self-created myth to reflect the idiosyncratic reality of the writer's and other generations. The old myth is thus employed to create a new story which is relevant and can communicate with the contemporary reader. Fiction is therefore "an attempt to draw on intuition, imagination, and metaphor to see more deeply into aspect of the experienced world."(Shaan, 2015:129) The process involves the use of artistic and linguistic devices to transform the mythical material into significant meanings for contemporary readers.

In this paper, we explain the origins and symbolic meaning of Achebe's myths in Anthills of the Savannah and how he uses the method of deconstruction to make such myths relevant to contemporary problems of leadership in Nigeria. We also reiterate the fact that Achebe is not the first or the only writer to take myths from the Bible and blend them with culture, history, tradition or current happenings in order to render these myths more utilitarian. His use of language redolent of violence is not new either: he follows in the tradition of writers who have employed same language to pres- ent similar levels of corruption. These aspects of the novel do not simply help us understand its meaning but they also explain the creation process of the literary piece, Achebe's stance on leadership problem in Nigeria and the idiostyle of the writer.

The relevance of this approach is that it offers another perspective on the interpretation of the story. This is because mythopoesis is an approach that leads to a "mythical, literary and artistic cross fertilization," and this makes the work rich enough for different approaches. (Kumar, 2017:125) Achebe's view is that the political mess in Africa has been created by men and that the infusion of women into the political affairs of the continent could help solve the problem.

\section{THE BIBLE AND THE PORTRAYAL OF CORRUPTION}

The Bible is a great source book for literary writers and critics. In this regard, Northrop Frye in The Anatomy of Criticism suggests that students of literature should study not only its stories but also its structure and language (Frye, 1959:12). Many great writers before Achebe have deconstructed myths 
from the Bible to capture the levels of moral and political corruption as well as the obsession with absolute power that have characterised humanity in general. In most of these works, the kind of language used follows the principle of the language of tragedy as prescribed by Aristotle in The Poetics. "Language with pleasurable accessories" should be used in presenting serious issues and in a similar fashion, Achebe uses language full of violence to decry the moral decadence and misuse of power in the world of the novel.(Blamires, 2009:8) All the arbitrary killings, the subjection of citizens to physical violence and all the Machiavellian tactics used by the president to preserve his power forever are presented in a language that is as distasteful as corruption itself. This is what helps the novelist to clearly put across his dislike for authoritarian rule in Nigerian and his preference for a true and all-inclusive type of leadership that is tempered by moderation. The same idiostyle has been used by both William Faulkner and Yeats in their mythopoesis of some biblical myths.

In William Faulkner's classic, Absalom, Absalom, the Biblical story of David and the classical story of Cadmus are employed as metaphors. David, the man after God's own heart, was unfortunately not a good example of a father. His lament when he heard the news of the death of his irresponsible son 'O my son Absalom, my son, my son Absalom! Would God I had died for thee ...!' (2 Sam 18:33) ${ }^{1}$ provides the title of Faulkner's novel. Cadmus in Greek mythology is another irresponsible father. He killed a dragon and sowed the dragon's teeth in the ground, from which sprang a race of fierce armed men. By throwing a stone among them, Cadmus caused them to fall upon one another until only five survived, who assisted him to build the Cadmeia or the citadel of Thebes' (Wikipedia). The allusions to David and Cadmus coupled with Faulkner's novelistic techniques tell a tale of the injustice and the hypocrisy of the American South with respect to black people. Faulkner's new story is about the unmaking of fathers who cannot manage their sons. Directly, it refers to America; a father who could not manage his two sons - blacks and whites. It is a timeless classic that continues to be relevant in a world where ethnic, racial and political schisms are rife.

Biblical accounts are deconstructed or deliberately distorted as Yeats does in his famous poem 'The Second Coming'. This well-known poem, which has become even more famous because almost every line has been used in the title or the subtitle of a book, is in two parts or stanzas, roughly representing the first and the second comings. The first part deals with a gargantuan breakdown of order where violence and chaos reign. This is the first part of the poem:

Turning and turning in the widening gyre

The falcon cannot hear the falconer;

Things fall apart; the centre cannot hold;

Mere anarchy is loosed upon the world,

The blood dimmed tide is loosed, and everywhere

The ceremony of innocence is drowned;

The best lack all conviction, while the worst

Are full of passionate intensity. ${ }^{2}$

${ }^{1}$ All references to the Bible are from the King James Version ${ }^{2}$ Freer Allen and Andrew John: Cambridge Book of English Verse, $1900-1939$ p. 34
Chaos and confusion are evident in the sentences 'Things fall apart' and 'Mere anarchy is loosed upon the world'. The word 'mere', an intensifier, paints a picture of purity; of anarchy that is unadulterated. The repetition of the word 'loosed' suggests the deliberate unleashing of anarchy and bloodshed on the world by an evil force or agency. It is a picture that conforms to the state of the world at that time: the First World War with its senseless waste of human life had just ended. These were convoluted times of revolutions - The October Revolution in Russia and the Irish Uprising - with violence and the loss of life which, taken together, would be said to have generated a 'blood dimmed tide'. The best people neither knew what to think nor do because the basic beliefs, taken for granted for centuries, had been undermined by these revolutions and so-called scientific advances. The phenomenal universal moral collapse that derives from this 'passionate intensity', the intoxicating effects of fanaticism, is therefore not surprising.

When the 'falcon cannot hear the falconer', 'the centre cannot hold'. Any dislocation of the lines of communication between the falcon and the falconer is recipe for anarchy. This represents a disintegration of the lines of authority, and thus of communication, between political/religious authority and the masses which inevitably triggers an avalanche of violence and bloodshed attributable mainly to the breakdown of the basic Christian fidelity and political suasion.

The second part of the poem makes a simple statement: this chaos, bloodshed or moral collapse fulfills the prophecy of Jesus about the imminence of his second coming:

Surely some revelation is at hand

Surely the Second Coming is at hand

The Second Coming! Hardly are those words out

When a vast image out of Spiritus Mundi

Troubles my sight; a waste of desert sand

A shape with lion body and the head of a man,

A gaze blank and pitiless as the sun,

Is moving its slow thighs, while all about it

Wind shadows of the indignant desert birds,

The darkness drops again but now I know

That twenty centuries of stony sleep

Were vexed to nightmare by a rocking cradle,

And what rough beast, its hour come round at last,

Slouches towards Bethlehem to be born? ${ }^{3}$

The Biblical significance of the poem is unmistakable from its title and clear Biblical allusions. There is the repetition of 'the Second Coming' (Lines 10,11), a clear reference to the Biblical Second Coming of Christ. It is a 'clear' reference because of the definite article 'the' and the initial upper case letters. There is the tide of blood almost like the sea of blood in the Biblical book of Revelation.'The vast image', and 'the rough beast' with the body of a lion and the head of a man are like those strange creatures we read about in Ezekiel, Daniel and the Revelations. The 'rocking cradle' (Line 20) and Bethlehem (Line 22) are references to places associated with the birth of Christ.

Even though we have these Biblical allusions, this is not the Biblical story but a deconstruction of it. The Bible

${ }^{3}$ Freer Allen and Andrew John: Cambridge Book of English Verse, 1900-1939 p. 34 
teaches that the second coming of Christ will bring peace and order to a troubled world but what the seer sees is a "vast image' (Line 11), a 'rough beast' (Line 20), 'a shape with lion body and the head of a man' slouching 'towards Bethlehem to be born'. Even before the persona informs us that this beast has 'a gaze blank and pitiless as the sun' (Line 16) we shudder at the unlimited capacity for evil in the combination of the thinking and planning; a head of a man on the strong and fast body of a lion, the king of the jungle. Yeats himself describes the destruction this beast is capable of as 'laughing, ecstatic destruction'. The Bible has strange creatures but it has nothing like this creature. Again, in connection with the birth of Christ, the Bible never mentions 'a cradle' but it is always 'a manger'. And surely, the creature 'slouching towards Bethlehem to be born' has not got the slightest resemblance to Christ. The new story then which Yeats has made out of this distortion of the Biblical accounts is that the first coming of Christ ended disastrously; the second coming is going to be even worse. This theme is expressed in a novel form in the universe of Achebe's Anthills of the Savannah.

\section{ACHEBE'S ANTHILLS OF THE SAVANNAH}

Chinua Achebe is one African novelist who has exploited the symbolic resources of Biblical narratives and traditional mythology. In Anthills of the Savannah, his prescriptions for Africa's political leadership problem are dispensed through his mythopoeic deconstruction of a Biblical narrative and of a traditional myth. The two offshoots of this mythopoeic mission dominate this novel: the Hymn to the Sun also called the Pillar of Fire and the Idemili myth or the Pillar of Water. The former is an epic prose poem; an apostrophe to the Sun. It reminds us of Yeats' line 'A gaze as blank and pitiless as the sun', for it describes in hyperbolic terms the desiccating power of the sun in Abazon in the northern part of Kangan, a thinly veiled Nigeria. It is a wasteland of 'crimson torches', 'furnaces of heaven', a 'roaring holocaust' and 'an incinerated world' of the 'bulging eye of madness'. (Achebe, 1987:30) This Hymn (Anthill of the Sanannah, Ch 3, pp. 30-33) ascribes the desiccation of the land not to the Almighty, but to the Sun, The cosmic nature of the repercussions is clear: birds, trees, household animals, the clouds and the earth itself receive death blows. Mercifully, the only human casualty described is a madman who taunts the villagers every market day with obscenities.

This reminds the narrator of another drought 'in legend' during which the hard 'earth broke the hoes of the grave-diggers and bent the iron tip of their spears' and death stared through the eyes of people. (Achebe, 1987:32) The people then abandoned their land, travelled south under terrible conditions and consequences, set upon the inhabitants of Ose, a small village, wiped them out, settled on the land and renamed the village Abazon. The people know that the present drought could end up as bad, if not worse than the one in legend, and so they send a deputation of their leaders to talk to the president, the modern Sun, 'who hold the yam today, and hold the knife'.(Achebe, 1987:33) The Hymn is thus about the abuse of power, a theme which is central to the novel. The Sun abuses his power and this is a pretext for the people of Abazon in the legend to abuse their power and to infringe on the rights of peaceful citizens.

In the prose-poem, the sun is variously described as 'the Single Eye of God', 'the Great Messenger of the Almighty', and 'the Great Carrier of Sacrifice to the Almighty'. The Sun has many of the attributes Christians ascribe to Jesus, the son of God. We note firstly, the word play on 'Sun' and 'Son', a pun which the Bible uses a few times. (See for instance Malachi 4:2, KJV) Jesus was sent down to the earth as a sacrifice for humankind, after which he carried his atoning sacrifice to his father the Almighty, thus procuring salvation for man. He is thus the 'Messenger of God' and 'the Great Carrier of Sacrifice to the Almighty'. He is also referred to as the 'Single Eye of God' for Christians insist that he is the only one through whom God looks at mankind and the only way of salvation for man. Achebe's hymn, however, subverts the supposed benign influence of Jesus Christ, the Son of God, on the earth and on Man. In the prose poem, the Sun sets himself up as the Almighty, rejects the sacrifice of man and wreaks terrible punishment on the earth and its inhabitants, creating a waste and devastation for an offence no one understands. And we are told that this is the second time the sun had done this and it 'could easily end worse'.

Interestingly, instead of the Sun terrorizing the people for the second time, the Daughter of the Almighty, Idemili, intervenes in the form of a resplendent Pillar of Water to counter the effects of the Sun. The second coming is thus not that of the Sun or Son but of the Daughter of the Almighty. Idemili is a simple Igbo traditional myth and Achebe follows it up with a ritual and an illustrative example:

In the beginning Power rampaged through our world, naked. So the Almighty, looking at his creation through the round undying eye of the Sun, saw and pondered and finally decided to send his daughter, Idemili, to bear witness to the moral nature of authority by wrapping around Power's rude waist a loincloth of peace and modesty. She came down in the resplendent Pillar of Water ... It rises majestically from the bowl of the dark lake pushing itself upward and erect ... At first that holy lake was the sole shrine to Idemili. But as people multiplied and spread across the world they built shrines farther and farther away from the lake ... As it happened, good land was more plentiful than good water and before long some hamlets too far from streams and springs were relieving their burning thirst with the juice of banana stems in the worst years of dry weather. Idemili, travelling through the country disguised as a hunter, saw this and on her return sent a stream from her lake to snake through the parched settlements ... (Achebe, 1987:102103).

The universality of the problem of power is marked by the convergence of the Yeatsian mythopoesis of 'The Second Coming' and Achebe's in Anthills of the Savan$n a h$. Both attribute some untold havoc unleashed upon man to the issue of power. It is as much a problem of man's use of power here as it is in Yeats's poem. Achebe has in his works lamented profusely the use of power by African leaders. In his 'Chinua Achebe: A Re-assessment', a paper delivered at the Conference of the Asso- 
ciation of Nigerian Authors (ANA) held at the University of Nigeria, Nsukka, Charles F. Nnolim sums up this tendency.

The theme of poor leadership which takes centre stage in The Trouble with Nigeria may come as a surprise to scholars and literary critics who have spent several decades poring over various themes and techniques in Achebe's novels; but they need not be surprised for from Things Fall Apart to Anthills of the Savannah the one consistent concern he exhibited in each novel is the issue of leaders who, in time of crisis, fail their people. (Nnolim, 1980:118)

In Anthills of the Savannah it would require Idemili's intervention to mitigate the havoc that leadership problems unleash. She is first sent down 'to bear witness to the moral nature of authority by wrapping around Power's rude waist a loincloth of peace and modesty' to moderate naked power by teaching men that authority should be handled with morality and modesty. (Achebe, 1987:102) She also quenches the thirst of people by sending them water when the sun has created a drought.

Achebe follows this narration with the rites a man who wants the ozo title has to perform. It seems it is Idemili's responsibility to give the ozo title to people and she shows her utter 'contempt for man's unquenchable thirst to sit in authority on his fellows' at every stage of this ritual. A young woman must hold the hand of the ambitious man like a child, and 'stand between him and the Daughter of the Almighty ... before he can be granted a hearing'.(Achebe, 1987:104) Idemili does not want to see the face of a man who wants power and so an innocent girl must mediate. The one running after the title is made to sit on seven fragile pieces of chalk so that none is broken. The fragile pieces of chalk symbolize frail human beings and the man of authority must be so gentle that none of the people are broken under the yoke of his power. Finally, Idemili's endorsement of the authority of man is done indirectly. She has a probationary period of not more than three years and so those she disapproves of die before the period ends to 'save her sacred hierarchy from contamination and scandal'. (Achebe, 1987:104)

There is then the example of a young man who takes the ozo title. The last ritual he has to perform is to stay continent in a bachelor's hut for twenty-eight days. Hypocritically, he stays there during the daytime and sneaks out at night to visit a widow he fancies for he thinks 'Why would a man mounting a widow listen for footsteps outside her hut when he knows how far her man has travelled?'. (Achebe, 1987:104) One dawn, as he is returning from his nocturnal activity, the royal python, messenger of the Daughter of God bars his way. The only alternative left to him is to go to his own hut in ignominy and to his death. The young man represents those who aspire to leadership positions but have no moral principles. Idemili's standard is that Power must always be balanced with morality, modesty and peace, failing which those wielding Power will be cut off in their probationary period.

It is quite clear that Achebe has taken liberties with both the Biblical and the traditional narratives in his bid to fashion out a peculiar personal myth that will express the contemporary problem in a way that is poignant and universal. It is a new myth which evolves from a blend of the foreign Biblical myth and the Igbo traditional myth. Here, the Jesus (the Son) figure blends into the Sun deity figure now referred to as 'the Single Eye of God', 'the Great Messenger of the Almighty', and 'the Great Carrier of Sacrifice to the Almighty'. The language is definitely Christian but the theology is non-Christian. This is not so surprising since it is a contemporary creation of a modern African writer brought up on the teachings of the Christian Scriptures about a drought that was contemporary. But Achebe may have his powerful reasons why a well-known traditional oral narrative like the story of Idemili should also be deconstructed this way. Tradition has it that Idemili is the only daughter of Chukwu and his wife Ala who have a family of seven children. ${ }^{4}$ Achebe decides to make her the Daughter of the Christian Almighty God, one of an all-girl family but retains her traditional characterization as a girl with a boy's naughtiness. Achebe is fashioning a new story in which the devastation of the Sun or Son is corrected by the Daughter of God.

Achebe manifestly states that the mess in Kangan, has a male signature to it. The novel establishes a clear link between Sam, the head of state and the Sun. Oblique and direct references in the story make Sam the Sun symbol. At the cabinet meeting, for instance, we are informed that the mood of Sam determines the general atmosphere of the meeting. Chris annoys Sam over Abazon and the fear in the room is clear but later the president brightens up and this is how Chris describes it: 'The fiery sun retires temporarily behind a cloud; we are reprieved and immediately celebrating.' (Achebe, 1987: 3) The Old Man from Abazon makes the strongest statement yet linking Sam and the Sun. He informs us that his delegation was sent to Bassa because some 'shifting-eyes people' came to Abazon to inform them that:

Because you said no to the Big Chief he is very angry and has ordered all the water bore-holes they are digging in your area to be closed so that you will know what it means to offend the sun. So we came to Bassa to say our own yes and perhaps the work on our bore-holes will start again and we will not all perish from the anger of the sun. ( $A S$, Ch. 9, p.116)

Sam wants to be Life President so he organises a referendum and the only province which votes against it thus torpedoing the whole idea is Abazon. The sun causes the drought which Sam in his vindictiveness intensifies by stopping the construction of bore holes in the area. The two perform the same role in denying the people water to drink. Ikem, in his introduction to the Hymn to the Sun tells his countrymen that things will not be fine for them until they overthrew 'the wild sun of April'. (Achebe, 1987: 28) Finally, the physical destruction caused by the sun is matched by the moral atrophy caused by the president.

The theme of abuse of power is central to the novel. In other words, power is not handled with modesty and peace. Power is abused by all types of leaders in all areas of activity: politics, society, school and home. Ikem suggests that Sam's power hunger began after his first OAU heads

${ }^{4}$ From the traditional tale retold by NnediOkorafor at www. lamfada.com, accessed on June 12th, 2008 
of state's meeting where he met the Emperor and the President-for-Life Ngongo. Sam learnt a few tricks from Ngongo, the life president. The life presidency referendum was probably one direct or indirect influence of Ngongo. Finally, the advice Ngongo gave Sam which had far reaching repercussions was about his boyhood friends: 'Your greatest risk is your boyhood friends, those who grew up with you in your village. Keep them at arm's length and you will live long.' (Achebe, 1987: 23) Later, when Sam attacks his boyhood friends, Chris and Ikem - it is based on the advice of the man he describes as 'the wise old tortoise'. Commenting on Sam and his misuse of power Larry Diamond remarks:

We see in this portrait a dictator obsessed with power and the need for absolute and total loyalty to himself, intolerant of the slightest opposition or criticism, and suspicious of plots against him. Isolated from the free flow of information power loses both perspective and accountability retreating into a narrow circle of lackeys and flatterers. The theme is old but timeless: power unchecked feeds on itself, becomes intoxicated with itself and seeks relentlessly to aggrandize itself. (Diamond, 1989: 25)

To ensure the security of their positions, the commissioners are led into fawning sycophancy; deferring, stooping and prostrating before the president, the man who appoints and dis-appoints, who hires and fires. Chris characterizes the cabinet as the 'cream of our society and the hope of the black race', yet the members shamelessly stoop to gossiping about others to curry favour with the president. The flattery is servile and blasphemous. 'This nation's Man of Destiny', 'We have no problem worshipping a man like you' (Achebe, 1987:23, 24) 'Your Excellency is not only our leader but also our Teacher' (Achebe, 1987:18) 'Their desire is manifest. You are condemned to serve them for life'. (Achebe, 1987:5). These comments intensify the link between Sam and the Sun or the Son.

Many characters in the novel refract authority from the centre either by their links with the head of state or by law, and thus the infection at the centre affects the peripheries. The poison is seen most clearly in the actions of Major Johnson Ossai, the director of the State Research Council. He is the president's personal choice and his loyalty; discipline and dedication make Sam quite happy. Ossai's preferred method of preliminary investigation is placing the suspect's hand between the teeth of a Samsonite paper-stapler 'and bang. The truth jumps out surprisingly fast'. (Achebe, 1987:23, 106) The state security apparatus he directs does all the dirty jobs for the president. The arrest and murder of Ikem, the hounding of Chris, the arrest and detention of the delegation from Abazon, the deportations of John Kent and the BBC reporter in Kangan who files a report about the assassination of Ikem are examples of the invaluable services Ossai and the SRC offer the president. Midnight is their preferred time for sensitive operations. They visit Ikem at midnight, leave his flat in shambles and assassinate him. The flat of Beatrice is also searched at midnight and the sergeant who lands the job of searching Beatrice's room does so with a vengeance. An orderly, presumably acting on instructions of the president imprisons the cabinet. The mobile policemen who beat and rape demonstrating university students refract authority from the centre. (Achebe, 1987:173) The open bribe-taking of the policemen on the Great North Road reflects the general indiscipline at the centre. So also is the case of the policeman who commandeers a truck-load of beer to celebrate the overthrow of the government and later openly attempts to rape a girl.

The men in the story are given power to sit in authority over their fellow human beings. They fail to satisfy Idemili, the Daughter of God, and so all these men - Sam, Chris, Ikem and Ossai - die within the three-year probationary period. Chris and Ikem are hounded to their death by Sam while a coup d'état sweeps Sam and Ossai out of power and out of life. The only credible group at the end of the novel is the one called the 'Ecumenical Fraternity' led by Beatrice, the priestess of Idemili. This group is well-structured and balanced in terms of religion, ethnicity, social class and gender. There are Christians, Muslims and traditional worshippers in the group. Beatrice, the priestess of Idemili has received a Christian baptism. Members of the group are from all parts of Kangan. Socially, it is a varied group: Beatrice is highly educated and a Senior Civil Servant, Abdul Medani is a military officer, Emmanuel Obete is a university student, a former student leader, Braimo is a taxi driver, Adamma is a student nurse while Elewa, Aina and Agatha are common people. So in this group, achievers team up with the common people under the leadership of a priestess to deliver good governance.

The real hope in the novel is Elewa's baby girl, born posthumously to Ikem. At the naming ceremony at the end of the novel, Achebe adroitly brings together the different generations and classes of people and all varieties of English - standard, pidgin and transliteration - together in a powerful statement of unity. This symbolizes the survival of hope beyond death and as Senanu writes, it is 'a tentative homecoming, a redeeming of the times'.(Senanu,1995) The girl is given a boy's name Amaechina which means May-the-pathnever-close. Achebe, in an interview has said that:

The implication of the path is really that it is only a boy who can keep the family homestead alive ... Girls don't count because they go out, they marry elsewhere ... This is why if you find a family that is having difficulty having a male issue, but finally succeeds, they are likely to call him Amaechina: their hope of immortality hangs on this one person.... This is all a narrow view of survival, which the naming ceremony in Anthills is challenging and calling into question. The fact that the old man accepts it without too much difficulty is a very encouraging sign. ${ }^{5}$ The child, the youngest member of the new generation, carries the attributes of the male and the female and also since all the members of the ecumenical fraternity had decided to be her father and mother, she is going to be a symbol of inclusiveness in tribe, class, religion and gender. She combines in herself also the intelligence and bravery of Ikem and the down-to-earth simplicity of Elewa, her mother. There is also the priestess of Idemili to guide her spiritually and so we have all the ingredients of good leadership.

${ }^{5}$ Larry Diamond in his essay 'Fiction of Political Thought', African Affairs Vol 88, No. 352, July 1989, p. 25 quoted from The Novels of Ngugi and Achebe 


\section{CONCLUSION}

Chinua Achebe is a latter day convert to the whole phenomenon of female liberation and empowerment. His earlier novels, especially Things Fall Apart and Arrow of God are highly patriarchal. But in The Anthills of the Savannah he summons two powerful witnesses - the Bible and tradition - to make a big point for female inclusion in the political process. From the Bible he picks the story of the first coming of Christ, twists it into having a malignant influence on the earth and its inhabitants. Through the many sun symbols, he makes the point that the devastation and poverty of Africa is male caused. From tradition, he brings Idemili, the Daughter of God who is involved in a benign second coming. The priestess of Idemili in the novel, Beatrice, is a powerful political force at the end of the novel but real hope is in Amaechina, the girl with a boy's name. Old myths retold in a different way through mythopoetics and deconstruction therefore lead to a better understanding and rendering of many "political, vital problems and social collisions.” (Barova, 2015:1031)

\section{NOTES:}

1. All references to the Bible are from the King James Version.

2. Freer Allen and Andrew John: Cambridge Book of English Verse, 1900-1939 p. 34

3. Kunapipi, Vol XII, 1990, p. 118.

4. From the traditional tale retold by NnediOkorafor at www.lamfada.com, accessed on June $12^{\text {th }}, 2008$.

5. Larry Diamond in his essay 'Fiction of Political
Thought', African Affairs Vol 88, No. 352, July 1989, p. 25 quoted from The Novels of Ngugi and Achebe.

\section{REFERENCES}

Achebe, Ch. (1987). Anthills of the savannah. New York: Doubleday.

Barova, Aly. G. (2015). The sources of mythological thinking of Elias Canneti. The Social Sciences, 10(6), 1026-1032.

Blamires, H. (2009). A history of literary criticism, Delhi: Macmillan Publishers India Ltd.

Ellman, R. (1948). Yeats, the man and the masks. New York: Macmillan.

Faulkner, W. (1978) Absalom, Absalom! New York: Vintage Books.

Frye, N. (1959) The anatomy of criticism. Princeton: Princeton University Press.

Indraseni, Red. (1994) The novels of Achebe and Ngugi. New Delhi: Prestige Books

Kumar, P.(2017) The broken wall, the burning roof tower: W. B. Yeats's revision of the Leda myth in historico-political contexts. Rupkatha Journal on Interdisciplinary Studies in Humanities, 3(ix), 125-131.

Senanu, K., and Williams, D. (Eds) (1995). Creative use of language in Kenya. The Jomo Kenyatta Foundation, Nairobi.

Shaan, S. (2015) A mythopoetic methodology.: as storytelling an act of scholarship. Asia Pacific Journal of Teacher Education, 2(43), 128-142. 